\title{
Article
}

\section{The Interaction Model within Phygital Environment as an Implementation of the Open Innovation Concept}

\author{
Alexey Aleksandrovich Mikheev ${ }^{1}$, Aleks Krasnov ${ }^{2, * \mathbb{D}}$, Richard Griffith ${ }^{3}$ and Mihail Draganov ${ }^{4}$ \\ 1 Moscow State Institute of International Relations (University), Ministry of Foreign Affairs of the Russian \\ Federation, 119454 Moscow, Russia; 7721177@gmail.com \\ 2 Institute of Industrial Management, Economics and Trade, Peter the Great St. Petersburg Polytechnic \\ University, 195251 St Petersburg, Russia \\ 3 School of Psychology, Florida Institute of Technology, Melbourne, FL 32901, USA; griffith@fit.edu \\ 4 Faculty of Management, Technical University of Sofia, 1000 Sofia, Bulgaria; mdraganov@tu-sofia.bg \\ * Correspondence: krasnov_as@spbstu.ru
}

Citation: Mikheev, A.A.; Krasnov, A.; Griffith, R.; Draganov, M. The Interaction Model within Phygital Environment as an Implementation of the Open Innovation Concept. J. Open Innov. Technol. Mark. Complex. 2021, 7, 114. https://doi.org/10.3390/ joitmc7020114

Received: 10 March 2021

Accepted: 15 April 2021

Published: 18 April 2021

Publisher's Note: MDPI stays neutra with regard to jurisdictional claims in published maps and institutional affiliations.

Copyright: (c) 2021 by the authors. Licensee MDPI, Basel, Switzerland. This article is an open access article distributed under the terms and conditions of the Creative Commons Attribution (CC BY) license (https:// creativecommons.org/licenses/by/ $4.0 /)$.

\begin{abstract}
Currently, the interaction of the consumer and the retail market on the basis of the digital technologies could be described from the point of view of open innovation concept. The article aims to prove the advantages of mixing two separate formats of the interaction between the seller and the consumer in online and offline. The scientific approach to the developing of the so-called phygital environment (physical plus digital) could be considered as a research gap. The definition of the phygital environment regards the innovational concept being used in marketing practice but has not been described in scientific publication yet. The article examines the peculiarities of interaction between consumers and sellers in the framework of their interaction in the phygital environment. The concept of pop-up stores is analyzed as a new format of advertising interaction with the consumer. The authors have proposed a model of an end-to-end analytics system for assessing the effectiveness of a pop-up store in the framework of the interaction of participants in the turnover in a phygital environment. The proposed model has been tested and the efficiency of opening a pop-up store has been evaluated with and without the proposed model. The main marketing indicators and potential effects from the implementation of the proposed system for the company's activities, in general, in the field of marketing are evaluated. The authors have studied the prospects for both development and automation, as well as the formation of the system of personalized marketing for companies, which implements the concept of interaction with consumers within the framework of the phygital environment.
\end{abstract}

Keywords: phygital environment; open innovations; digital marketing; pop-up store

\section{Introduction}

The modern retail market is developing at a faster pace than ever before, driven by high rates of development in all areas of science and technology that directly affect the retail industry. Along with this, consumer behavior is also changing: consumers go online and return offline, which ensures interaction between the seller and the consumer within the so-called phygital environment. However, interaction with consumers in two formats does not allow marketing specialists to reliably assess the effectiveness of interaction with consumers for each of the individual promotion channels, which significantly reduces the efficiency of management decisions.

The year 2019 turned out to be less efficient for the Russian trade industry compared to 2018 , as the trade turnover amounted to USD 666,558 million, which is $3.13 \%$ less than that in 2018. At the same time, imports showed an increase of $2.36 \%$ (5629 million US dollars), while exports decreased by $6.04 \%$ (27,187 million US dollars) [1]. 
The format of online retail is developing, but the volumes of classic trade are also not decreasing, which indicates the ambiguity of the situation between the online and offline markets [2]:

- online stores try to open offline stores, attracting customers with various advantages, including free shipping, fitting, returns, etc.;

- $\quad$ offline stores, on the contrary, are trying to actively develop the Internet market and increase revenues at the expense of regions in which offline stores were not previously represented.

The purpose of this study is to build a model of end-to-end analytics in the framework of interaction with consumers in an online and offline environment at the same time using the example of a new store format.

The aim of this study is to develop marketing interaction between the manufacturer and the consumer, which can be expressed in improving the accuracy of marketing research and increasing the company's ability to be customer-oriented. The concept of the model should not only be focused on interaction with the client, but also on solving global problems: reducing overproduction. The solution to this socially significant problem will reduce the damage to the environment at the time of destruction of unclaimed goods.

\section{Methods}

\subsection{Theoretical Fundamentals for the Descriptions of the Phygital Environment}

Many studies show that today's consumers are becoming more selective in their choice of products, which indicates a change in consumer behavior, forcing sellers and manufacturers to create a more targeted and personalized offer that is most likely to interest the buyer. With the advent of the Internet environment, it has become much easier to identify and study the behavior of both individual consumers and groups of consumers with common features. By analyzing the digital footprint, it is possible, without interfering with the personal life of the buyer, to find out with high accuracy his preferences and type of behavior. Thus, online trade can interact much more accurately with the consumer and satisfy his needs. However, for offline stores, creating a personalized offer specifically targeting each consumer is a complex and high-cost project.

The modern interaction of the consumer and the retail market has led to the creation of a theory of a special environment called phygital.

Phygital (physical plus digital) is a marketing term that describes blending digital experiences with physical ones. As the channels of customer interaction and communication proliferate, companies aim to make combining these channels frictionless and seamless, without the company losing the thread of the communication or a sense of the customer issues [3].

Phygital marries both the online and offline environments by trying to take the best aspects from each space to create a much more complete and satisfying customer experience [4].

Phygital is the concept of using technology to bridge the digital world with the physical world with the purpose of providing a unique interactive experience for the user [5].

To maintain a leading position in the market, companies must actively promote, both online and offline, for successful promotion. However, it often becomes difficult for the marketing department to determine the effectiveness of promotion channels, as traffic intersects: consumers learn about a product online and purchase it offline, and vice versa. One of the solutions to this problem is to build a system of end-to-end marketing analytics that will assess the effectiveness of marketing costs, taking into account the return of consumers both online and offline. Thus, companies need to build a concept of customer interaction within a phygital environment. 
For a complete understanding of the differences and similarities between the organization of trade in the framework of physical, phygital, and digital consumer behavior, a comparative Table 1 was compiled by analysis of different sources [6-12].

Table 1. Comparison of physical, phygital, and digital environments.

\begin{tabular}{cccc}
\hline & Physical & Phygital & Digital \\
\hline Point of sale of goods & Offline Stores & Offline + Online Stores & Online Stores \\
\hline Product selection process & $\begin{array}{c}\text { Directly in the store, contact } \\
\text { with the product is required }\end{array}$ & $\begin{array}{c}\text { Using online stores to check out a } \\
\text { product, but buying from a real } \\
\text { store (or vice versa) }\end{array}$ & $\begin{array}{c}\text { Comparison of product } \\
\text { parameters using online } \\
\text { catalogs }\end{array}$ \\
\hline Payment method & Mostly cash & Bank card & Bank card, e-currency, etc. \\
\hline Typical representative & Generation X & Generation $Y$ & Generation Z \\
\hline Interaction model & $\begin{array}{c}\text { Creation of a wide choice for } \\
\text { any category of buyer }\end{array}$ & $\begin{array}{c}\text { Creation of a personal offer in a } \\
\text { wide choice (online + offline } \\
\text { analysis) }\end{array}$ & $\begin{array}{c}\text { Create a personalized } \\
\text { proposal based on digital } \\
\text { footprint analysis }\end{array}$ \\
\hline
\end{tabular}

A person strives to get the greatest benefit from using the Internet, nevertheless a transition is currently taking place when the consumer is not yet fully ready to abandon physical interaction with the retailer in favor of online shopping. Most often this is expressed in a preliminary search for goods on the Internet, but the purchase occurs directly in a retail store after personal interaction. It is graphically depicted in Figure 1.

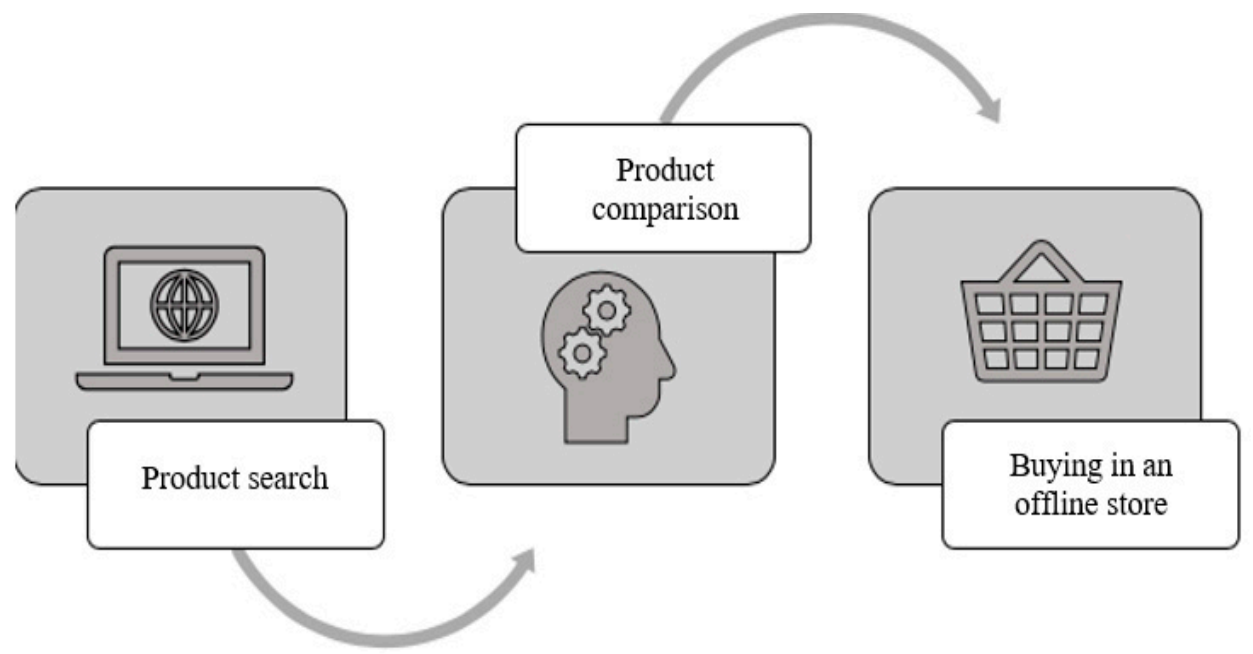

Figure 1. Product selection process in a phygital environment.

An abrupt and one-time transition of all consumers to Internet commerce cannot occur, due to various factors (non-ubiquitous spread of the Internet, the difficulty of delivering goods, varying degrees of trust in Internet commerce, etc.). This trend is confirmed by the theorists of marketing such as Rogers [13,14] and Bass [14,15]. Thus, a new environment is formed in which buyers and sellers interact with each other in order to achieve the most satisfying result for both parties.

\subsection{The Theoretical Approach to Model of Interaction of the Main Components in a Phygital Environment}

The interactions within the phygital environment that arise between buyers and sellers are of a special nature, which requires specialized approaches to analyze marketing interactions. To build an end-to-end analytics system within the phygital environment, a new format of offline stores was chosen-pop-up store. 
A pop-up store is a temporary storefront space operated by an online merchant [16].

A pop-up retail is a retail store (a "pop-up shop") that is opened temporarily to take advantage of a faddish trend or seasonal demand [17].

The first pop-up store, in full accordance with the concept, was opened in 2004 by the Japanese company CommeDes Garcons in Berlin [18]. Absolutely not using advertising and other means of disseminating information about the opening of a new store, the pop-up store of this company was very popular with customers, thanks to this because it existed in one place for a year, and then the store was opened in other large cities of Europe in the already tested and proven efficiency format.

First of all, exclusive brands such as Louis Vuitton [19], Chanel [20], Prada [21], and Yves Saint Laurent [22] began to use the concept of a pop-up store. One of the most famous pop-up stores is Hermes Silk Bar, which was opened between 2009 and 2010 in Hong Kong. In 2011, the sportswear and footwear brand Adidas opened its unusual store at the Primavera music festival. This store became very popular due to the chosen stylistic design - the store was made in the form of a shoe box for the Adidas originals collection, which is one of the most recognizable trademarks in the world. In addition, in 2011, the Swedish clothing brand H\&M opened its pop-up store on one of the most popular Dutch beaches in anticipation of the beach season, where it sold swimwear for women, men, and children [23].

For these companies, the creation of a low-budget store does not have a significant impact on income, but it allows you to check the attitude of buyers to new collections and "warm up" the interest of buyers before launch. Thus, it allows for additional marketing research in relation to a specific product or group of products. This store format appeared on the Russian market quite recently and has existed for about five years, but its popularity is growing every year. Malls provide special conditions for short-term retail outlets, which helps mall receive more profit not only from renting space for standard stores, but also from previously unused areas, such as aisles between store rows, wide areas inside the center, parking lots, etc.

Comparison analysis of traditional and pop-up-stores, prepared by sources [24,25], is presented in Table 2.

Table 2. Comparison of traditional and pop-up stores.

\begin{tabular}{ccc}
\hline Location & Traditional Store & Pop-Up Store \\
\hline Rent type & $\begin{array}{c}\text { They can be located in a specialized area for } \\
\text { trade, in malls, in residential buildings, in } \\
\text { detached buildings. }\end{array}$ & $\begin{array}{c}\text { They can be located in various public places: } \\
\text { beaches, central streets, public transport, } \\
\text { malls, exhibitions, museums, etc. }\end{array}$ \\
Rent price & Long-term rental & Short-term rent, from one day to 12 months \\
\hline Range of products & $\begin{array}{c}\text { Depends on the area of the trade enterprise } \\
\text { and revenue for the period. It is an } \\
\text { insignificant part of selling expenses. }\end{array}$ & $\begin{array}{c}\text { Depends on the size of the enterprise, utility } \\
\text { costs. It makes up the largest part of } \\
\text { expenses. }\end{array}$ \\
\hline Area (sq.m.) & The entire product range & Individual products \\
\hline
\end{tabular}

If we consider a pop-up store not only as a point of sale for goods, but also as an advertising object, which by means of location, and appearance, attracts customers who have not previously paid attention to the presented brand, then it becomes important to assess how many new customers were attracted by a particular new project. Thus, the company will be able to evaluate the pop-up store not only from the financial point of view, but also as a separate ad format.

To solve the above problem, a model for evaluating the effectiveness of a pop-up store is proposed through the selection, counting, and correlation of buyers. This model will allow not only assessing the effectiveness of a pop-up store, but also interacting with customers in the long term, creating the most profitable and attractive offer. 
The main goal of the seller-manufacturer within the framework of the phygital environment concept is to correlate a real buyer who makes purchases in an offline store and an Internet user, from whom you can find out preferences, lifestyle, determine needs and create a trajectory of interaction based on the received data, which will be beneficial for both parties to build further relationships. To assess the effect of implementing an end-to-end analytics system using the example of a pop-up store, the following model was developed for assessing consumer interaction with the sales system (Figure 2), taking into account the peculiarities of the Phygital environment.

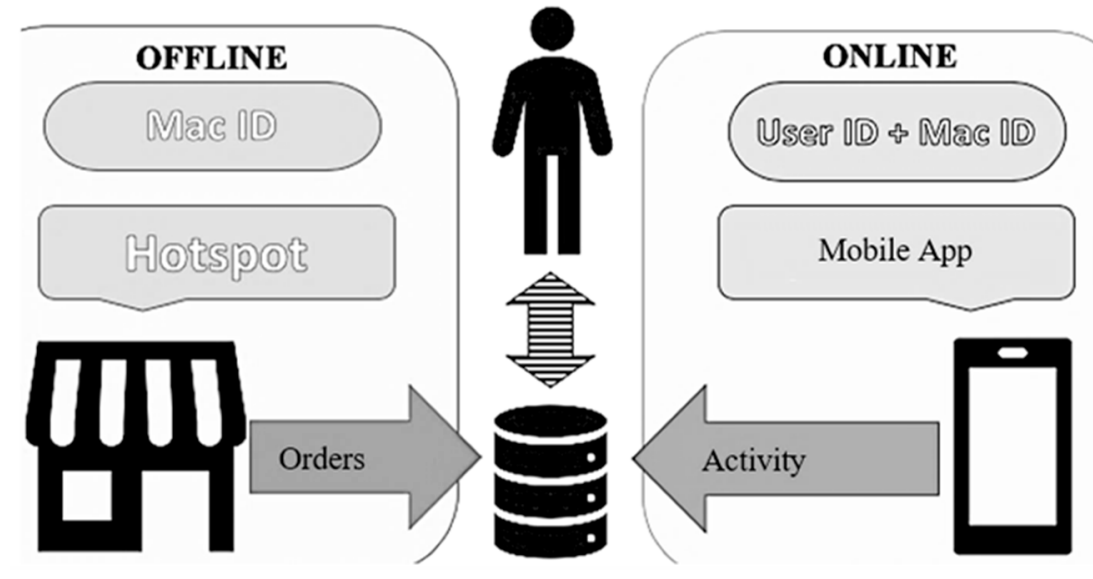

Figure 2. Model of interaction of the main components in a phygital environment.

The model (Figure 2) takes into account the specifics of interaction between a consumer and a manufacturer in a digital environment, as well as the specifics of the analyzed indicators for end-to-end analytics systems (advertising, traffic, attraction channels, web analytics, etc.) [26-31].

The consumer performs various types of actions in two spaces-online and offline. As noted earlier, to create the most detailed portrait of the consumer, it is necessary to study both areas of interaction. But the most important and difficult task is to correlate a customer in an online environment with the same customer in an offline environment, and study his behavior in both environments.

The offline environment is represented by stores where the buyer can directly make purchases, while assessing the organoleptic properties of the goods. In stores, each customer can be identified by introducing loyalty programs and personal accounts in applications on personal mobile devices or official websites. These personal profiles transmit data to the hotspot, which in turn generates information for a shared database. Each customer is assigned an individual Mac ID, which distinguishes an individual customer from the general group, and also guarantees security and anonymization of data. The collection of Mac ID occurs at the moment when the customer crosses the border of the store and enters the range of specialized fixing devices that are Wi-Fi modules. It should be noted that the safety of the buyer is ensured by coding data without relying on a specific person, which cannot be used for personal purposes.

The online environment is represented by online stores, which are inextricably linked with the traces of consumer activity in the Internet environment (digital footprint) and allow to form a circle of interests and needs of a particular buyer. In the Internet environment, each user registers himself independently, creating a User ID, a personal profile that accumulates all information about the user and sends it to the database.

Thus, the database accumulates, correlates, and forms a specific list of buyers with the characteristics of their behavior and preferences, so that sellers and manufacturers can make an offer more targeted and useful. 


\section{Results}

3.1. The Suggested Tools for Improving the Phygital Environment Model

The main tools which authors suggest using in the phygital environment could be:

1. Mobile application. A constant companion of any modern person is a mobile device, a smartphone, which allows to have access to the Internet at any time and place. Manufacturers and retailers gain access to information that is accumulated in a mobile device, immediately after the owner's permission, and process it to further improve the efficiency of interaction with the buyer, committing to keep the personal data of the buyer safe [32-34].

2. Wi-Fi modules. Specialized devices that are capable of recording and collecting information from personal devices that fall within their coverage area (radius), performing these actions using wireless Wi-Fi data transmission, can be used for various purposes, both by large companies and small businesses. Using these devices, you can track the exact number of buyers who were attracted by a specific advertising channel, movement of buyers through the trade enterprise, personal preferences in the selection process, etc. [35-37].

The Wi-Fi points installed in the sales area, at the entrance to the store and at advertising points, will help to record consumer behavior during the purchase. These devices help you track the Mac IDs assigned to each personal device. More specifically, when analyzing the data obtained, the following information can be obtained and processed:

1. The number of new, repeat, and regular customers-Wi-Fi points installed at the entrance to the store can record all devices entering the store, and when analyzing for a certain period, customers can be divided into different groups depending on their loyalty and other behavioral features. An important note is the necessarily working Wi-Fi mode on the user's device.

2. Average time spent in the store-this indicator allows you to assess how comfortable the customer is in the store, to determine the most and least active hours.

3. Route of the customer's movement through the store-different types of customers can move around the store in different ways, and depending on the data received, you can change the tab of goods, focusing on specific groups of consumers. By summarizing data on movement with data on the time spent by customers, it is possible to identify the most problematic places in the store, where a large group of people is periodically formed, which does not allow other customers to make purchases comfortably and require rearrangement of equipment.

4. Map of hot and cold spots in the store-using this tool, you can most effectively generate a map of the display of goods in the store, which will focus the attention of consumers on specific commodity items.

The most effective advertising points-if you install Wi-Fi points near advertising positions, then specific devices will record and indicate their movement, assessing the number of buyers who eventually arrived in the store. With this data, you can accurately say about the most effective points of outdoor advertising and abandon the least effective. In addition, this tool most accurately measures the effectiveness of pop-up stores.

\subsection{The Suggested Model for Constructing a System of End-To-End Analytics of the Pop-Up Stores}

To assess the efficiency of a trade enterprise operating in the pop-up store format [38], all performance indicators that are usually used to evaluate trade enterprises are suitable; however, the authors chose ROI as the main indicator, which allows evaluating the effectiveness of investments.

Return on Investment (ROI) is a performance measure used to evaluate the efficiency of an investment or compare the efficiency of a number of different investments. ROI 
tries to directly measure the amount of return on a particular investment, relative to the investment's cost [39] and to social media [40-42].

$$
\text { ROI }=\frac{\text { Current Value of Investment }- \text { Cost of Investment }}{\text { Cost of Investment }} \times 100 \%
$$

The expenses of organizing a pop-up store are presented in Table 3.

Table 3. Expenses of opening a pop-up store.

\begin{tabular}{cc}
\hline Expenses (E) & $\mathbf{1 0 , 8 4 4 , 0 0 0 . 0 0 ~ P}$ \\
\hline Rent (E1) & $5,400,000.00 \mathrm{P}$ \\
Equipment and installation (E2) & $1,734,000.00 \mathrm{P}$ \\
-equipment(E21) & $876,000.00 \mathrm{P}$ \\
-installation work (E22) & $858,000.00 \mathrm{P}$ \\
Products (E3) & $450,000.00 \mathrm{P}$ \\
Payroll (E4) & $1,800,000.00 \mathrm{P}$ \\
Payroll burden (E5) & $540,000.00 \mathrm{P}$ \\
Promotion (E6) & $920,000.00 \mathrm{P}$ \\
\hline
\end{tabular}

Based on the results of the functioning of the pop-up store and the assessment of sales volumes within the framework of the proposed end-to-end analytics system for the phygital environment, the authors obtained the following results of the outlet's activity (Table 4).

Table 4. Revenue based on the results of assessing the activities of the pop-up store.

\begin{tabular}{cc}
\hline $\begin{array}{c}\text { Revenue within the End-To-End Analytics System (for the } \\
\text { Period of Operation of the Pop-Up Store) (R) }\end{array}$ & $\mathbf{1 6 , 3 4 9 , 9 0 0 . 0 0 ~ P}$ \\
\hline Pop-up store revenue: (R1) & $7,522,200.00 \mathrm{P}$ \\
-initial visit (R11) & $6,534,800.00 \mathrm{P}$ \\
-repeat visit (R12) & $987,400.00 \mathrm{P}$ \\
Revenue of the main store after visiting the pop-up store (R2) & $4,803,600.00 \mathrm{P}$ \\
-products presented in the pop-up store (R21) & $634,200.00 \mathrm{P}$ \\
-other products (R22) & $4,169,400.00 \mathrm{P}$ \\
Follow-up sales through the mobile app (R3) & $4,024,100.00 \mathrm{P}$ \\
-products presented in the pop-up store (R31) & $805,200.00 \mathrm{P}$ \\
-other products (R32) & $3,218,900.00 \mathrm{P}$ \\
\hline
\end{tabular}

Based on the analysis of the collected data, it was revealed that two ROI indicators can be determined:

ROI within the pop-up store functioning. The return on investment in this case will be estimated as the ratio of the revenue from sales in the pop-up store, adjusted for sales through the offline store and the mobile application for the positions presented in the pop-up store and will be calculated using the formula:

$$
R O I=\frac{(R 1+R 21+R 31-(E-E 21))}{(E-E 21)} \times 100 \%=-10.1 \%
$$

Thus, the ROI in this case is $-10.1 \%$, which indicates that the operation of the pop-up store was not profitable and, to a greater extent, confirms the fact that pop-up stores are elements of brand formation and increasing awareness.

ROI within the end-to-end analytics system proposed by the authors:

$$
R O I=\frac{(R-E)}{E} \times 100 \%=50.8 \%
$$


The adjusted ROI on subsequent sales allowed us to determine that the ROI of a store of this format is $150.8 \%$, which indicates the profitability of this project. In addition, based on the structure of revenue, it can be concluded that $45.1 \%$ of the revenue was made up of purchases by visitors of other commodity items not presented in the pop-up store, and about $60 \%$ of sales refer to a return visit to any of the points of sale convenient for the visitor. About $25 \%$ of sales of the total revenue for the period of operation of the pop-up store turned out to be repeat purchases, which allows us to mark the most loyal customers.

Thus, the model proposed by the authors for constructing a system of end-to-end analytics allows the most accurate assessment of the effectiveness of the marketing activities implemented, which was demonstrated by the example of the functioning of the pop-up store. Through the registration technologies using WiFi-modules Mac ID and using systems of personal account/loyalty cards, User ID allows not only to take into account the actions performed by the visitor in online and offline points of sale, but also to establish a sequence of such actions, which allows you to better study the features of consumer behavior and establish patterns of consumer choice.

\section{Discussion: The Connection between the Phygital Environment and the Open Innovation Concept}

\subsection{Discussion: A Phygital Environment Concept}

The model of the end-to-end analytics system proposed by the authors may turn out to be a useful tool for functioning within the framework of the phygital environment concept; however, this model requires elaboration of the following key points for full functioning:

1. It is necessary to develop a system for analyzing data collected from various devices to build accurate sequential chains of consumer interaction with the company's points of sale;

2. The system allows to divide sales channels into offline and online, to determine the effectiveness of a separate offline sales point, but requires consolidation with a web analytics system to determine the effectiveness of individual online sales channels;

3. Solution of the issue of hiding the Mac ID for Wi-Fi modules;

4. It is important to determine the ultimate goal of such a system: the authors see it in building a system for forming a personalized offer to the consumer.

The urgency of solving these problems is confirmed by other scientific studies $[43,44]$.

Solving these issues will make this end-to-end analytics system more effective and contribute to the development of the formation of a personalized offer within the phygital environment.

Of course, the implementation of such systems should be accompanied by obtaining consent to collect information from users. The mobile application makes it easier to obtain such consent, while the interaction with the consumer's device through the Wi-Fi point is carried out without his consent. The solution to this problem is possible only in conjunction with local authorities and the administration of malls by placing warning notices.

The attraction of these participants is possible if the emphasis is placed correctly. If we can prove the socially beneficial effect of the introduction of such open innovations, then the policy of their implementation can be agreed on from all sides. The main advantage of the proposed model is an increase in the accuracy of forecasting demand, and as a result, a decrease in the volume of production. Thus, it has not only been personally beneficial, but also had a socially significant effect, reducing waste and improving the environmental situation in the world [45]. The implementation of such a system will provide the main benefits by considering open innovation: improving the accuracy of marketing research and customer orientation, and also creates the potential for viral marketing [46,47]. 


\subsection{Discussion: Open Innovation Engineering from the Phygital Environment Concept}

The article [48] proves the logic of the connection between network processes being developed in the frameworks of the phygital environment and open innovation concept. The authors take into account the Christensen's determinants of open innovation model associated with the industrial dynamics of an industry segment undergoing a process of radical technological innovation [49], unraveling the Chesbrough's Open Innovation concept. The authors are trying to discuss the main idea of the contribution of the emerging literature on open innovation by deepening our understanding of the motivations for an exchange of knowledge among different subjects of the economic relations. The following issues could be considered:

- Open innovation engineering;

- Open innovation and serial entrepreneurs;

- The fit between firms' open innovation and business model for new product development;

- $\quad$ Bringing open innovation to services;

- Open innovation in value networks.

The Open Innovation Engineering could be considered from the point of view of the phygital environment concept. The authors could discuss that the innovation process in the frameworks of the phygital environment refers to the general topic of product innovation (and the corresponding process of pioneer market shaping [50]). The research could be treated from the point of view of the implementation of innovative activities. So, the discussion should be based on the fundamental theory of JinHyo Joseph Yun, considering the open innovation engineering model including both open-innovation engineering channels and determining ways of operating the channels through conceptual experiments [51]. The fundamental study of incentives and information [52] was expanded and implemented for open innovation and Schumpeterian new combinations [53,54], as well as open innovation based business model design compass [55].

The work [56] studies the boundary conditions that determine whether open or closed types of innovation management will actually lead to the highest value for a given firm. In this regard, the researchers should pay attention to the business model innovation aiming to succeed a competitive advantage on the basis of the sufficiently differentiated business model being hard to replicate for incumbents and new entrants alike [57]. We could agree that Business concept innovation is a central pillar in business model innovation [58]. Open innovation in value networks could be studied by analyzing some issues including theoretical perspectives since they are a nexus of value creation, non-arm's-length transactions, external resource sourcing, and inter-organizational networking [59].

\section{Conclusions}

Within the framework of this article, the authors proposed the interaction model within the phygital environment as an implementation of Open innovation concept for building an end-to-end analytics system in the framework of the interaction of companies with consumers in a special type of marketing environment considering blending digital experiences with physical ones (physical plus digital, i.e., phygital environment). The article studies the case when such a system was tested on the example of such an offline advertising element as a pop-up store, which is also a point of sale.

The developed model can be used both by representatives of large businesses with large retail space and by small businesses that need to earn the loyalty of each customer through an individual, personalized approach [60].

For a pop-up store, the developed model allows to assess most of the specific performance indicators such as conversion, traffic, number of new customers, and most importantly, the sales channel.

For a clear confirmation of the effectiveness of the proposed model for the analyzed pop-up store, the indicators of investment efficiency were calculated. The results obtained allowed us to conclude that the proposed model allows not only to more accurately assess 
the efficiency of investments, but also provides more data about the point of purchase, the moment of purchase, the selected positions and consumer loyalty.

The model proposed by the authors will not only improve the company's analytics system, but will also allow the transition to the development of an automated decisionmaking system-including the formation of a personalized offer, which will increase consumer loyalty and maintain their interest in the company-and enable the company to take a leading position in the market.

Author Contributions: All the authors have contributed substantially to the entire work reported. Conceptualization, A.K. and A.A.M.; data curation, A.A.M. and R.G.; methodology, R.G. and M.D.; writing—drafting, A.K.; writing—inputs, all authors; writing—reviewing and editing, all authors. All authors have read and agreed to the published version of the manuscript.

Funding: The study was supported by the Academic Excellence Project 5-100 proposed by Peter the Great St. Petersburg Polytechnic University.

Data Availability Statement: Data available in a publicly accessible repository.

Acknowledgments: The authors would like to thank the anonymous referees for their very useful suggestions.

Conflicts of Interest: The authors declare no conflict of interest.

\section{References}

1. Russian Foreign Trade Reports and Reviews. Available online: https://en.russian-trade.com/reports-and-reviews/2019-12/ (accessed on 14 December 2020).

2. Akkus, I.E.; Chen, R.; Hardt, M.; Francis, P.; Gehrke, J. Non-tracking web analytics. In Proceedings of the ACM Conference on Computer and Communications Security, Raleigh, NC, USA, 16-18 October 2012.

3. Lauren Horwitz Phygital. Available online: https://searchcustomerexperience.techtarget.com/definition/phygital (accessed on 14 December 2020).

4. FLOR, C.S.D. LA What's Phygital in the Customer Experience? Available online: https://www.wearemarketing.com/blog/ whats-phygital-in-the-customer-experience.html (accessed on 14 December 2020).

5. Phygital. Available online: https://www.monash.edu/business/marketing/marketing-dictionary/p/phygital (accessed on 14 December 2020).

6. Batat, W. Phygital customer experience. In Experiential Marketing: Consumer Behavior, Customer Experience and the 7Es; Taylor \& Francis: Milton Park, UK, 2019.

7. Samir, M.; Soumia, A. Phygitalization of the customer experience: A qualitative approach. Int. J. Mark. Commun. New Media 2020, $6,56-73$.

8. Miller, R.T. Getting "Phygital”: Embracing the space where digital and physical intertwine. School Libray Journal. 4 September 2015. Available online: https:/ / www.slj.com/?detailStory=getting-phygital-embracing-the-space-where-digital-and-physicalintertwine-editorial (accessed on 17 April 2021).

9. Belghiti, S.; Ochs, A.; Lemoine, J.-F.; Badot, O. The phygital shopping experience: An attempt at conceptualization and empirical investigation. In Academy of Marketing Science World Marketing Congress; Springer: Cham, Switzerland, 2018.

10. Arora, S.; Verma, A. M-commerce: Crusader for "Phygital" retail. In M-Commerce: Experiencing the Phygital Retail; CRC Press: Boca Raton, FL, USA, 2019.

11. Soloviov, E.; Danilov, A. The beginning of phygital world. South Asian J. Eng. Technol. 2020, 10. [CrossRef]

12. Duhan, P.; Singh, A. M-commerce: Experiencing the phygital retail. Glob. J. Enterp. Inf. Syst. 2017, 9. [CrossRef] [PubMed]

13. Rogers, E.M. Diffusion of Innovations, 4th ed.; Simon \& Schuster: New York, NY, USA, 1995; ISBN 0028740742.

14. Krasnov, A.; Chargaziya, G.; Griffith, R.; Draganov, M. Dynamic and static elements of a consumer's digital portrait and methods of their studying. In IOP Conference Series: Materials Science and Engineering; IOP Publishing: Bristol, UK, 2019.

15. Bass, F.M. A new product growth for model consumer durables. Manag. Sci. 1969, 15, 215-227. [CrossRef]

16. What Is a Pop-Up Shop? Available online: https://www.bigcommerce.com/ecommerce-answers/what-pop-shop/ (accessed on 14 December 2020).

17. Hayes, A. Pop-Up Retail Definition. Available online: https://www.investopedia.com/terms/p/pop-up-retail.asp (accessed on 14 December 2020).

18. Fortini, A. Anti-Concept Store. The New York Times, 12 December 2004. Available online: https://www.nytimes.com/2004/12/12 /magazine/anticoncept-concept-store-the.html(accessed on 14 December 2020).

19. Retail Design Blog Louis Vuitton Pop-Up Store. Available online: https://retaildesignblog.net/2019/07/19/louis-vuitton-popup-store/ (accessed on 14 December 2020). 
20. Chanel News Pop-Up Store in Moscow. Chanel. Available online: https://www.chanel.com/ru/fashion/news/2017/11/a-popup-store-in-moscow.html (accessed on 14 December 2020).

21. Retail Design Blog Prada Pop-Up Store, Tokyo-Japan. Available online: https://retaildesignblog.net/2017/06/26/prada-pop-upstore-tokyo-japan/ (accessed on 14 December 2020).

22. Luxus+ An YSL Beauty Pop Up Store in Coachella. Available online: https://luxus-plus.com/en/yves-saint-laurent-beautyunveils-a-pop-up-store-in-coachella-ruinart-partners-with-metiers-rares-and-the-other-news-of-the-day/ (accessed on 14 December 2020).

23. Retail Design Blog H\&M Beach Pop-Up Store. Available online: https://retaildesignblog.net/2011/06/20/hm-beach-pop-upstore/ (accessed on 14 December 2020).

24. Case study: The launch of a pop-up store. In PopUp Republic; John Wiley \& Sons, Inc.: Hoboken, NJ, USA, 2015; pp. 143-148.

25. Ruff, C. 6 Ways Brands and Retailers are Using Stores to Boost Business. Available online: https://www.retaildive.com/news/6ways-brands-and-retailers-are-using-stores-to-boost-business/519784/ (accessed on 13 December 2020).

26. Lee, I. Social media analytics for enterprises: Typology, methods, and processes. Bus. Horiz. 2018, 61, 199-210. [CrossRef]

27. France, S.L.; Ghose, S. Marketing analytics: Methods, practice, implementation, and links to other fields. Expert Syst. Appl. 2019, 119, 456-475. [CrossRef]

28. Hua, H. Marketing space 4.0-Mobile end-to-end marketing. In Mobile Marketing Management; Routledge: Milton Park, UK, 2019

29. Lagodiienko, V.; Karyy, O.; Ohiienko, M.; Kalaman, O.; Lorvi, I.; Herasimchuk, T. Choosing effective internet marketing tools in strategic management. Int. J. Recent Technol. Eng. 2019, 8, 5220-5225. [CrossRef]

30. Belozerov, D.; Belyaev, N. Development of end-to-end marketing analytics for saas solutions in the business market segment (b2b). Bull. South Ural State Univ. Ser. Econ. Manag. 2018, 12, 131-139. [CrossRef]

31. Constant, N.; Borthakur, D.; Abtahi, M.; Dubey, H.; Mankodiya, K. Fog-assisted wIoT: A smart fog gateway for end-to-end analytics in wearable internet of things. arXiv 2017, arXiv:1701.08680.

32. Barnes, S.J. The mobile commerce value chain: Analysis and future developments. Int. J. Inf. Manag. 2002, 22, 91-108. [CrossRef]

33. Yap, C.E.L.; Lee, J.J. "Phone apps know a lot about you!": Educating early adolescents about informational privacy through a phygital interactive book. In Proceedings of the Interaction Design and Children Conference, London, UK, 17-24 June 2020.

34. Fourati, A.; Ayed, H.K.B.; Kamoun, F.; Benzekri, A. Security issues of m-commerce over hotspot networks. In Proceedings of the 2004 IEEE Wireless Communications and Networking Conference, Atlanta, GA, USA, 21-25 March 2004.

35. Falcone, P.; Colone, F.; Lombardo, P. Potentialities and challenges of WiFi-based passive radar. IEEE Aerosp. Electron. Syst. Mag. 2012, 27, 15-26. [CrossRef]

36. Chetty, K.; Smith, G.E.; Woodbridge, K. Through-the-wall sensing of personnel using passive bistatic wifi radar at standoff distances. IEEE Trans. Geosci. Remote Sens. 2012, 50, 1218-1226. [CrossRef]

37. Falcone, P.; Colone, F.; Macera, A.; Lombardo, P. Localization and tracking of moving targets with WiFi-based passive radar. In Proceedings of the IEEE National Radar Conference, Atlanta, GA, USA, 7-11 May 2012.

38. Vesina, A. New Pop-Up Store by UNIQLO. Available online: https://e-mm.ru/professional/view/novyj_popup_magazin_ uniqlo_5338/ (accessed on 14 December 2020).

39. Fernando, J. Return on Investment (ROI) Definition. Available online: https:/ / www.investopedia.com/terms/r/returnoninvestment. asp (accessed on 14 December 2020).

40. Fisher, T. ROI in social media: A look at the arguments. J. Database Mark. Cust. Strateg. Manag. 2009, 16, 189-195. [CrossRef]

41. Duboff, R.; Wilkerson, S. Social media ROI marketers are seeking to answer the "greatest question". Mark. Manag. $2010,19,37$.

42. Kumar, V.; Mirchandani, R. Increasing the ROI of social media marketing. MIT Sloan Manag. Rev. 2012, 41, 17-23. [CrossRef]

43. Bozhuk, S.G.; Evdokimov, K.V.; Maslova, T.D.; Pletneva, N.A. Problems and perspectives of sustainable marketing development on the Russian food market. In IOP Conference Series: Materials Science and Engineering; IOP Publishing: Bristol, UK, 2019.

44. Bozhuk, S.; Maslova, T.; Kozlova, N.; Krasnostavskaia, N. Transformation of mechanism of sales and services promotion in digital environment. In IOP Conference Series: Materials Science and Engineering; IOP Publishing: Bristol, UK, 2019.

45. Bai, Y.; Ochuodho, T.O.; Yang, J. Impact of land use and climate change on water-related ecosystem services in Kentucky, USA. Ecol. Indic. 2019, 102, 51-64. [CrossRef]

46. Striukova, L.H. Chesbrough, Open Innovation: The New Imperative For Creating and Profiting from Technology; Harvard Business School Press: Brighton, MA, USA, 2005. [CrossRef]

47. Aldieri, L.; Vinci, C.P. Climate change and knowledge spillovers for cleaner production: New insights. J. Clean. Prod. 2020, 271, 122729. [CrossRef]

48. Barykin, S.Y.; Kapustina, I.V.; Sergeev, S.M.; Yadykin, V.K. Algorithmic foundations of economic and mathematical modeling of network logistics processes. J. Open Innov. Technol. Mark. Complex. 2020, 6, 189. [CrossRef]

49. Christensen, J.F.; Olesen, M.H.; Kjær, J.S. The industrial dynamics of Open Innovation—Evidence from the transformation of consumer electronics. Res. Policy 2005, 34, 1533-1549. [CrossRef]

50. Erkut, B. The emergence of the ERP software market between product innovation and market shaping. J. Open Innov. Technol. Mark. Complex. 2018, 4, 23. [CrossRef]

51. Yun, J.J.; Kim, D.; Yan, M.R. Open innovation engineering-Preliminary study on new entrance of technology to market. Electron. 2020, 9, 791. [CrossRef] 
52. Vohra, R.V. Mechanism Design: A Linear Programming Approach; Cambridge University Press: Cambridge, UK, 2011; ISBN 9781107004368.

53. Williams, K.C. The Handbook of Experimental Economics; Kagel, J.H., Roth, A.E., Eds.; Princeton University Press: Princeton, NJ, USA, 1995; 721p. [CrossRef]

54. Smith, V.L. Experimental economics: Induced value theory. Pap. Exp. Econ. 2010, 100-105. [CrossRef]

55. Yun, J.J. Business Model. Design Compass. Open Innovation Funnel to Schumpeterian New Combination Business Model. Developing Circle; Springer: Singapore, 2017; ISBN 978-981-10-4126-6.

56. Torkkeli, M.T.; Kock, C.J.; Salmi, P.A.S. The "open innovation" paradigm: A contingency perspective. J. Ind. Eng. Manag. 2009, 2, 176-207. [CrossRef]

57. Teece, D.J. Business models, business strategy and innovation. Long Range Plann. 2010, 43, 172-194. [CrossRef]

58. Souto, J.E. Business model innovation and business concept innovation as the context of incremental innovation and radical innovation. Tour. Manag. 2015, 51, 142-155. [CrossRef]

59. Chesbrough, H.; Vanhaverbeke, W.; West, J. Chapter 13: Open innovation in value networks. In Open Innovation: Researching a New Paradigm; Chesbrough, H., Vanhaverbeke, W., West, J., Eds.; Oxford University Press: Oxford, UK, 2006.

60. Bozhuk, S.G.; Maslova, T.D.; Pletneva, N.A.; Evdokimov, K.V. Improvement of the consumers' satisfaction research technology in the digital environment. In IOP Conference Series: Materials Science and Engineering; IOP Publishing: Bristol, UK, 2019. 